\title{
Macrophage Scavenger Receptor Types I and II
}

National Cancer Institute

\section{Source}

National Cancer Institute. Macrophage Scavenger Receptor Types I and II. NCI

Thesaurus. Code C112507.

Macrophage scavenger receptor types I and II (451 aa, $\sim 50 \mathrm{kDa}$ ) is encoded by the human MSR1 gene. This protein plays a role in cholesterol and lipoprotein transport. 